\title{
The Indian Springs \#2 Site(41BW512): A Late 18th Century Kadahadacho Settlement in Northeast Texas
}

Timothy K. Perttula

Heritage Research Center, Stephen F. Austin State University

Follow this and additional works at: https://scholarworks.sfasu.edu/ita

Part of the American Material Culture Commons, Archaeological Anthropology Commons, Environmental Studies Commons, Other American Studies Commons, Other Arts and Humanities Commons, Other History of Art, Architecture, and Archaeology Commons, and the United States History Commons

Tell us how this article helped you.

This Article is brought to you for free and open access by the Center for Regional Heritage Research at SFA ScholarWorks. It has been accepted for inclusion in Index of Texas Archaeology: Open Access Gray Literature from the Lone Star State by an authorized editor of SFA ScholarWorks. For more information, please contact cdsscholarworks@sfasu.edu. 


\section{The Indian Springs \#2 Site(41BW512): A Late 18th Century Kadahadacho}

Settlement in Northeast Texas

\section{Creative Commons License}

\section{(c) (1) (8)}

This work is licensed under a Creative Commons Attribution-NonCommercial 4.0 International License 


\title{
THE INDIAN SPRINGS \#2 SITE (41BW512): A LATE 18th CENTURY KADOHADACHO SETTLEMENT IN NORTHEASTERN TEXAS
}

\author{
Timothy K. Perttula
}

The Indian Springs \#2 site (41BW512) is on a high alluvial terrace or bluff edge (330 ft. amsl), overlooking the Red River floodplain and Hubbard Slough, an old channel of the river. The current channel of the river is ca. $1.6 \mathrm{~km}$ north of the site.

The site appears to be a late $18^{\text {th }}$ century Kadohadacho settlement with a small cemetery, although there is evidence in the collections known to have come from it that it was also occupied in Archaic and Early Caddo times (ca. A.D. 900-1200) as well as in the early to mid- $19^{\text {th }}$ century. The site was discovered by the landowner, Mr. Julian Cranfill during earth-moving activities associated with construction of a pond. When European glass beads were noted by Mr. Cranfill on the disturbed ground surface, he began a limited excavation of the area where the beads were found, attempting to ascertain their context and what other kinds of artifacts may be associated with them.

He excavated a circular area about 3-4 $\mathrm{m}$ in diameter along the eastern side of the bluff, on a small knoll (Figure 1). During this work, he documented three obvious cultural features (I-III) and a dark charcoal-stained patch of burned soil that may represent remnants of a shallowly-buried burned structure (Figure 2).

Feature I and Il (see Figure 2) are burials of Caddo people, and both had European glass beads and pottery vessels placed in the grave as funerary objects. Feature III is a pil that contained butchered hog jaws; it may be associated with the later $19^{\text {th }}$ century AngloAmerican farm occupation also present at the site.

The Feature I burial pit was oriented east-west, and was the size of a child or subadult burial (Figure 3). The burial pit extended to ca. $66 \mathrm{~cm}$ bs, and the bottom $2-5 \mathrm{~cm}$ of the pit fill was a very dark soil. This soil is probably the product of firing episodes associated with Caddo burial ceremonies (Gonzalez 2005:58).

There was a large concentration of glass beads at the eastern end of the burial, probably from necklaces of beads that were worn by the deceased. More than 3000 beads came from this area, along with a few preserved teeth, and three ceramic vessels.

Feature II was a larger burial pit, probably that of an adult Caddo, oriented almost north-south (see Figure 2). According to Mr. Cranfill, there were four ceramic vessels, more than 430 glass beads, and five triangular Fresno arrow points accompanying this individual.

\section{Artifact Collection from the Indian Springs \#2 Site}

Because historic Caddo archaeological sites are so rare in northeastern Texas and the Red River valley, I thought it was important to document the artifact collections from the Indian Springs \#2 site to better understand the age of the Caddo occupation and the range of European trade goods present there. Mr. Cranfill graciously provided permission for us to study his collections, take photographs and notes, and also excavate a few shovel tests on the site (see Figure 1) to get a sense of the character of the archaeological deposits on it. At the time of our visit in 1993, the site area was in an overgrown pasture. 


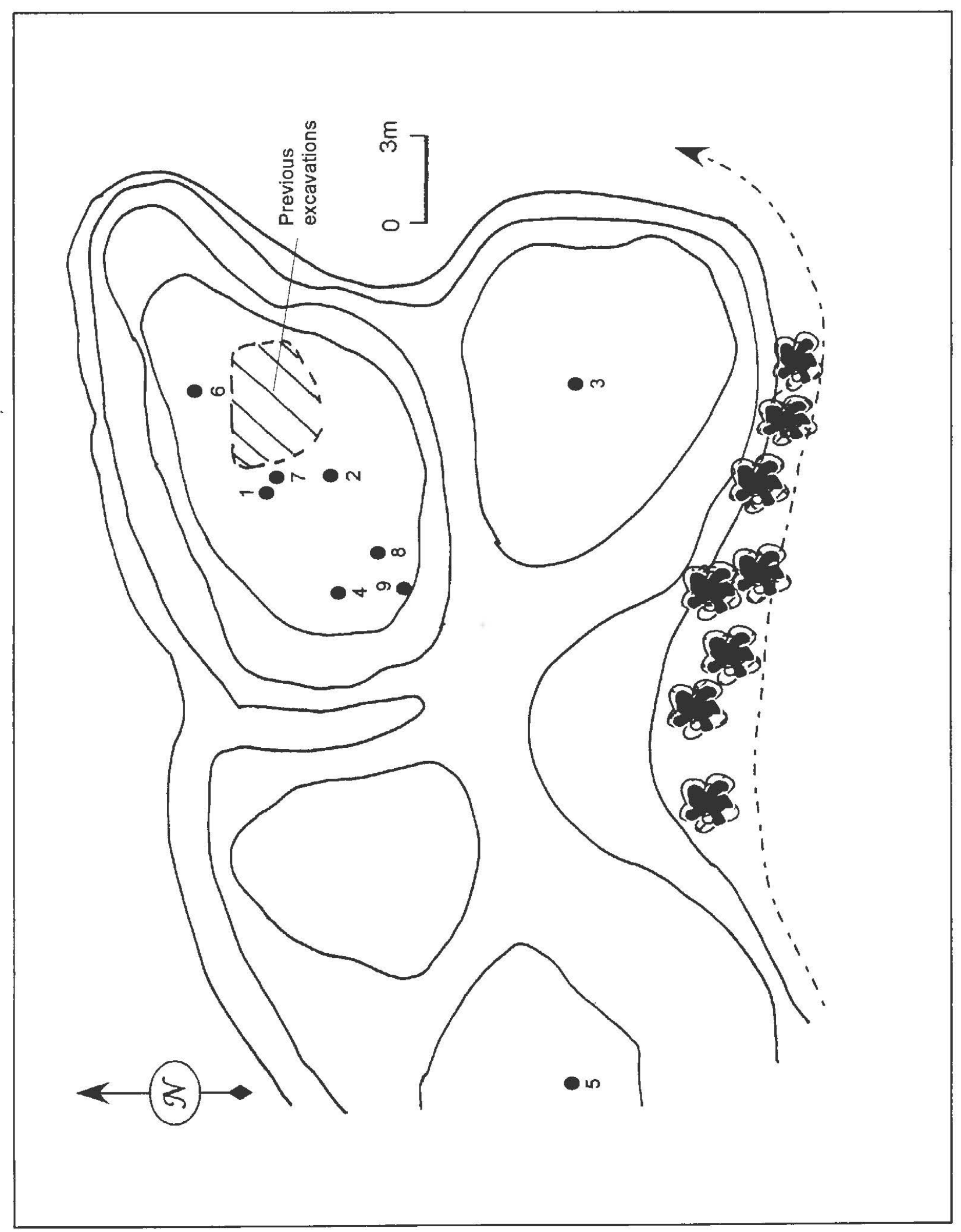

Figure 1. Map of the Indian Springs \#2 site (41BW512). 


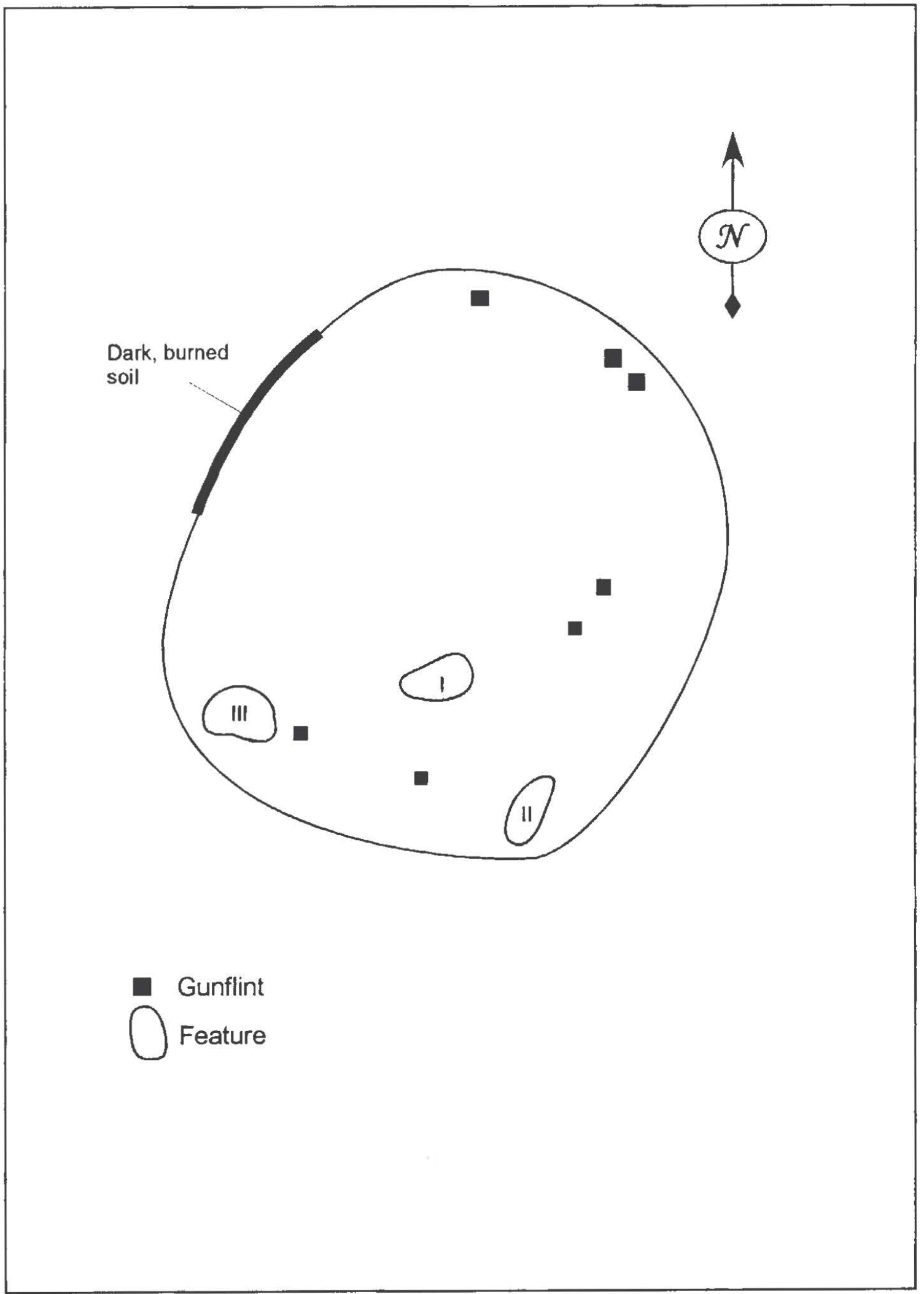

Figure 2. Plan of excavations by Julian Cranfill, and location of features I-III, and gunflints. 


\section{Feature 1}
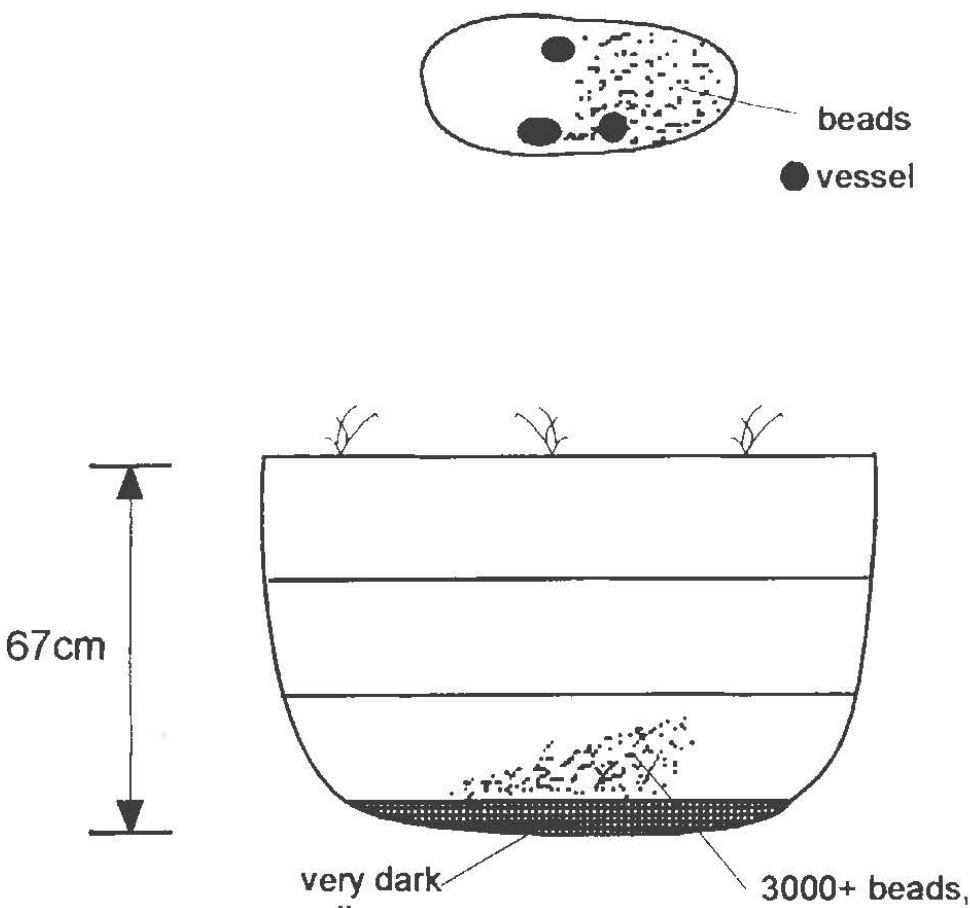

soil 20 human teeth, 3 vessels, and sherds

Figure 3. Plan and profile of Feature I, a burial of a Caddo child. 


\section{Ceramic Vessels}

Four vessels from the two burials were documented from the Indian Springs \#2 site. The first is a diminutive Natchitoches Engraved carinated bowl (Figure 4a-b). It is decorated with distinct rectilinear and meandering scroll bands on both the rim, body, and encircling the base, with ticked lines between each of the bands. Natchitoches Engraved vessels have been found only on historic Caddo sites dating from the late $17^{\text {th }}$ century to the late $18^{\text {th }}$ century, but the actual date at which they were no longer made by the Kadohadacho is not known. No Natchitoches Engraved sherds were identified in the ceramic collections from the ca. 1800-1840 Sha'chahdinnih Kadohadacho site near Caddo Lake (Parsons et al. 2002:27-32), but the sample of engraved sherds was very small.
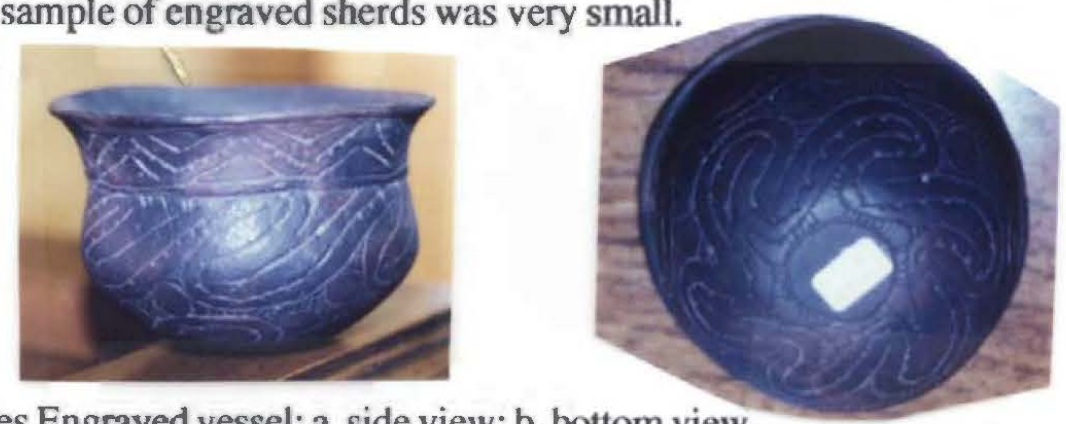

Figure 4. Natchitoches Engraved vessel: a, side view; b, bottom view.

The second vessel is an everted rim globular jar (Figure 5) with hatched and crosshatched engraved pendant triangles at the lip and neck-body juncture). Given the age and context of this vessel, the large pendant triangle motif is much like that seen on Womack Engraved vessels from other Caddo sites (Harris et al. 1965:Figure 6a; Story et al. 1967: Figure 50; Parsons et al. 2002; Walker 1935: Figure 2b) in northeastern Texas, and may be a later stylistic variety of that type. It also very much resembles in shape and decoration an engraved jar in the collections of the Brooklyn Museum (Perttula 2001:Figure 1) that was collected either from early $19^{\text {th }}$ century Caddo settlements in northwestern Louisiana or later $19^{\text {th }}$ century Caddo settlements on the Brazos Reserve. This particular jar has bands of cross-hatched pendant triangles between other bands filled with cross-hatched engraved panels.

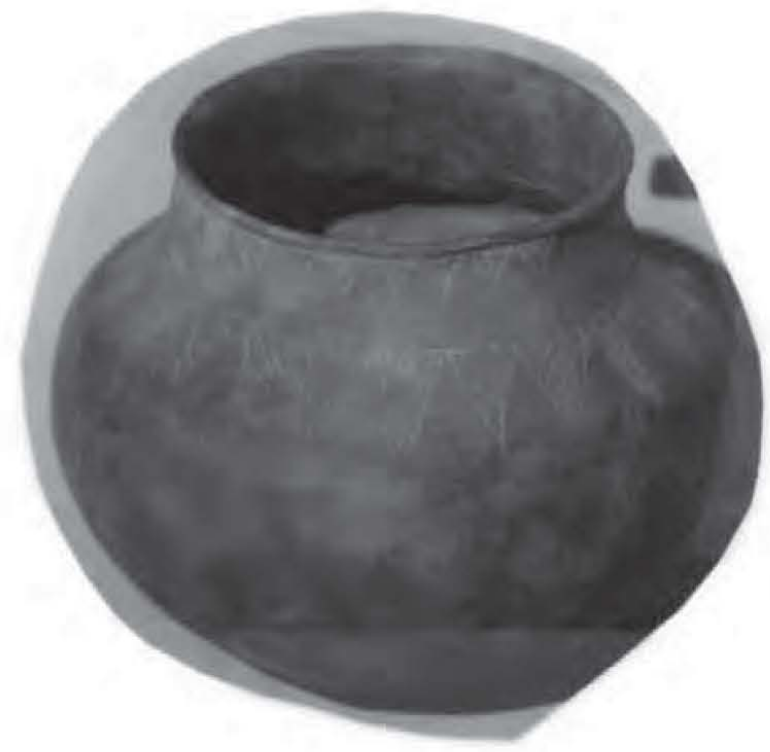

Figure 5. Engraved jar, possible Womack Engraved. 
The third vessel is a Simms Engraved carinated bowl (Figure 6). It has a discontinuous scroll with downward-pointing tick marks. Simms Engraved vessels with the same motif and similar vessel shapes have been documented in a late $17^{\text {th }}$-early $18^{\text {th }}$ century context at the Clements site (41CS25, see Gonzalez et al. 2005:Figure 4.10a-b), and there are virtually identical Simms Engraved vessels from the Hatchel site (41BW3) in the Texarkana Museum Systems collections (Gonzalez et al. 2005:33).

Figure 6. Simms Engraved vessel.

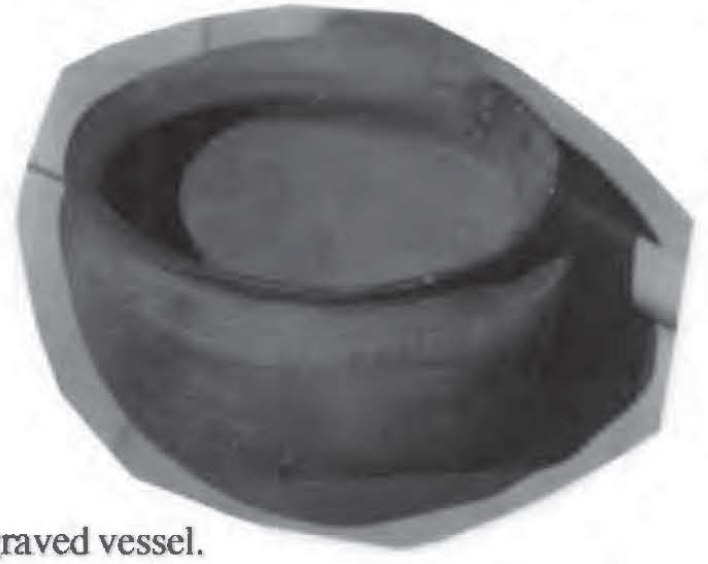

The last vessel is an everted rim jar with an incised and noded decoration on the vessel body (Figure 7). The incised decoration consists primarily of vertical lines that begin as cross-hatched lines at the rim-body juncture and extend to near the vessel base. Several of the vertical incised lines wrap around the four sets of nodes on the upper body (see Figure 7). This particular vessel may be an Emory Punctated-Incised jar (Story et al. 1967:137), as not all Emory Punctated-Incised jars have both incised lines and punctated row decorations on them.

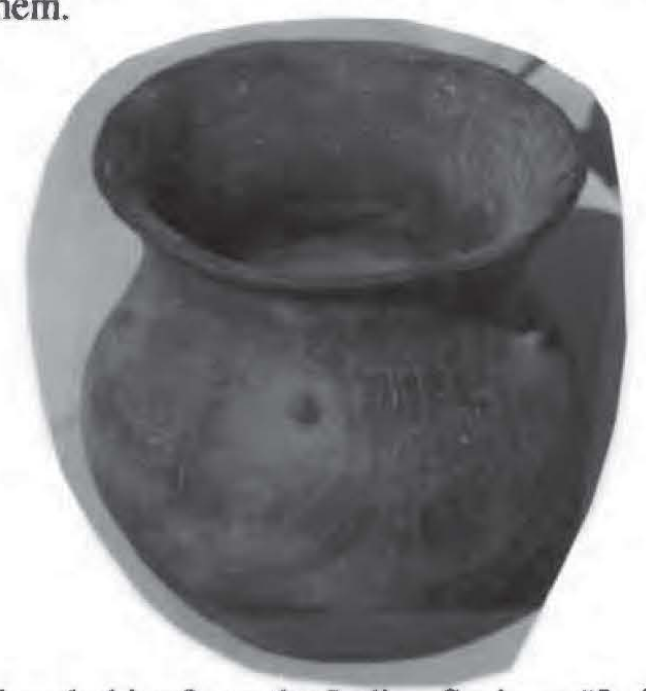

Figure 7. Incised and noded jar from the Indian Springs \#2 site.

\section{Ceramic Sherds}

In a collection of several hundred rim and body sherds from the site, a total of 21 decorated sherds were identified. None of the sherds appear to have been shell-tempered, but many had been tempered with burned animal bone. 
Five of the sherds have brushed decorations, either as vertical $(n=3)$ or overlapping $(n=1)$ brushing on jar bodies and horizontal brushing $(n=1)$ on the rim. Four body sherds have deep, trailed lines, and may be from Keno Trailed vessels.

The four punctated sherds have rows of tool $(n=3)$ or cane $(n=1)$ punctations on the rim below the lip. The decorative style of punctated rows on utility ware jars suggests these sherds may be from Emory Punctated-Incised vessels or a similar kind of punctated jar (ef. Mockingbird Punctated, see Gonzalez et al. 2005).

Four of the six incised sherds have only a single straight line from an indeterminate decorative motif. One other has a single curvilinear incised line. The last incised sherd in the collection has part of a large cross-hatched incised element.

There are only two engraved sherds in the Cranfill collection from the Indian Springs \#2 site. One is a bottle sherd with a hatched zone, probably part of a scroll from either a Natchitoches Engraved, Hodges Engraved, or Womack Engraved vessel. The other, likely part of a Natchitoches Engraved or Simms Engraved vessel, has a cross-hatched engraved zone above another engraved line with tick marks.

\section{Glass Beads}

There are approximately 3500 glass beads in the Cranfill collection from the Indian Springs $\# 2$ site. The vast majority of them (more than $95 \%$ ) are small drawn white glass seed beads of simple construction (Figure 8a-f and Figure 9a). There are also a few small blue and black drawn beads (see Figure 8c-f). A medium-sized black drawn bead was found at the Willis Place \#2 site (41BW147), situated about $400 \mathrm{~m}$ north of the Indian Springs \#2 site, along with an iom hawk bell (Perttula and Blaine 1998).

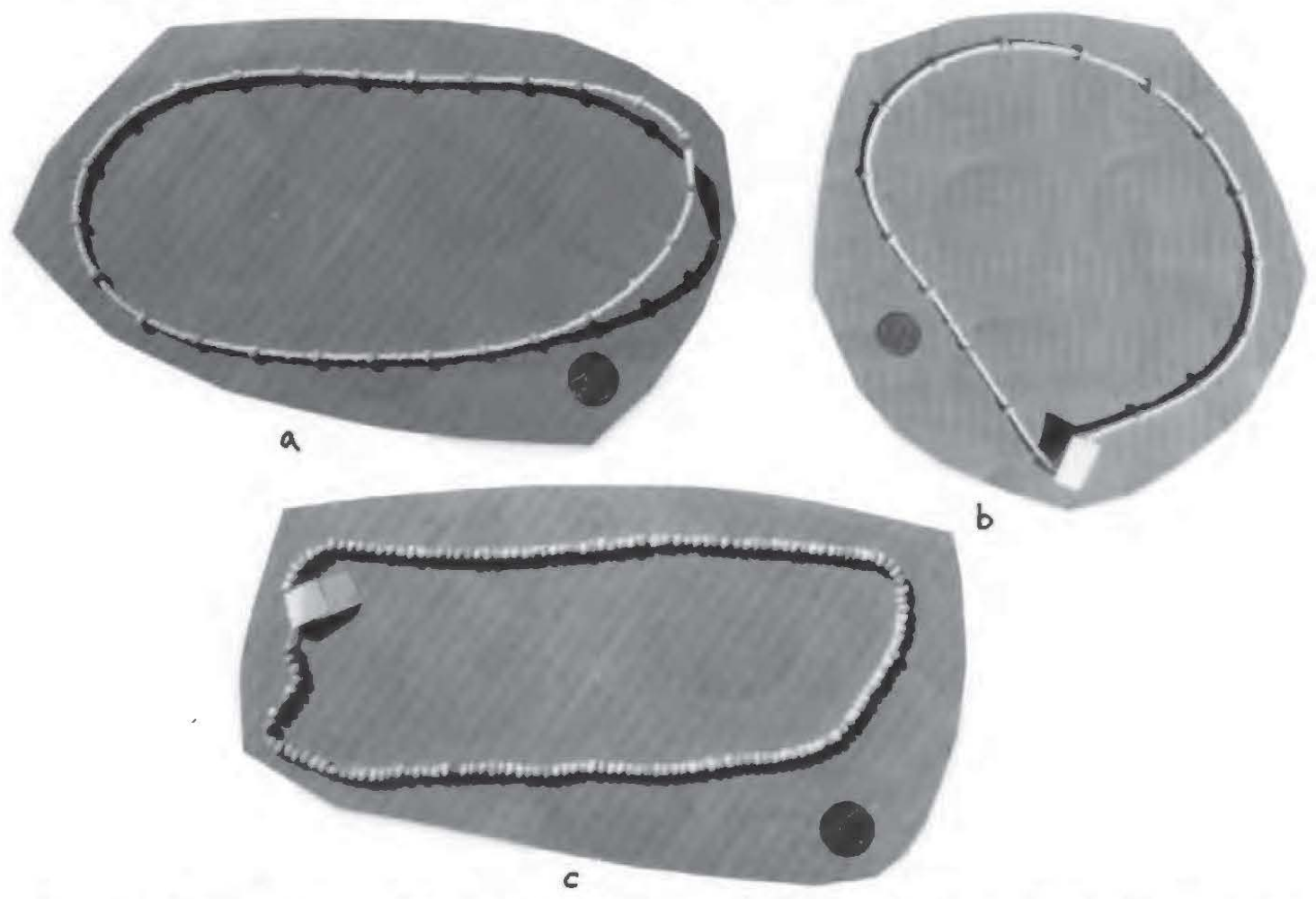

Figure 8. Strands of small drawn beads from the Indian Springs site \#2 (41BW512):a-c. 


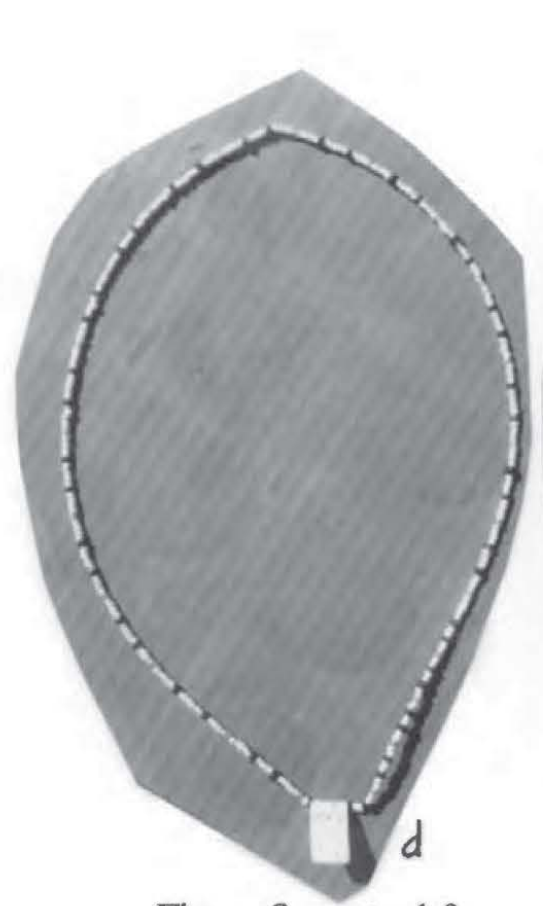

Figure 8, cont., d-f.
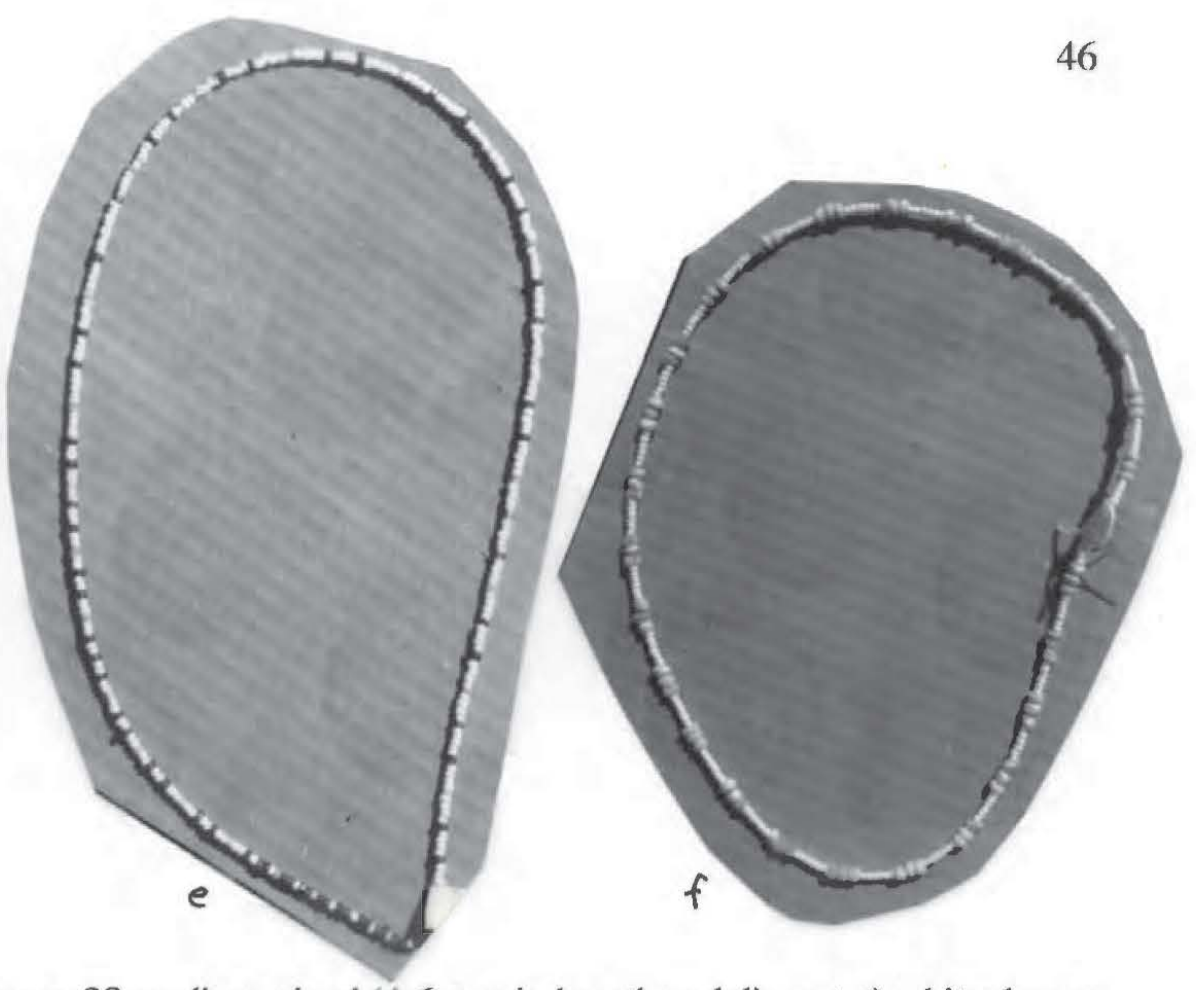

In addition, there are 28 medium-sized (4-6 $\mathrm{mm}$ in length and diameter) white drawn beads (see Figure $9 \mathrm{~b}$ ), and seven distinctive large wire-wound white beads in the collection (see Figure $9 \mathrm{c}$ ). According to Smith (2002:59 and Plate $2,4^{\text {th }}$ row), this kind of wound bead has only been found on archaeological studies associated with the French (or French trade) that postdate A.D. 1720, and it was common in the 1730s. He also mentions that they were in use until at least the mid-1750s.
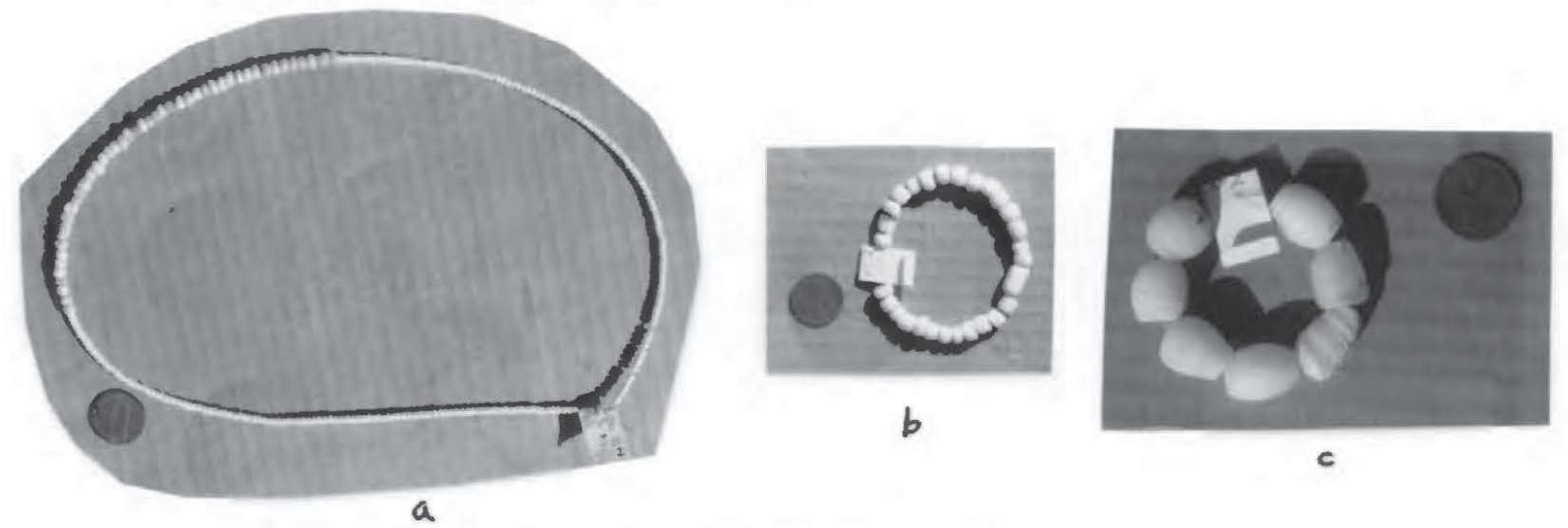

Figure 9. White glass beads of different sizes and shapes.

The great predominance of small drawn seed beads from the Indian Springs \#2 site suggests that the Kadohadacho occupation mainly dated after ca. 1760. This is based on a chronological sequence of bead types from Texas and northwestern Louisiana, where sites with more than $75 \%$ small seed/drawn beads, and very few medium-sized to large beads, appear to date from ca. 1760 to the early part of the $19^{\text {th }}$ century (Perttula 2005: Table 2).

\section{Gunflints}

There are nine gunflints in the collection, and they were widely distributed in Cranfill's excavation (see Figure 2). All nine are blade gunflints not made by the Caddo but by European flint knappers, with two from a black chert (and probably made from an 
English chert) and the other seven from a honey-colored French chert (Figure 10, top row, $3^{\text {rd }}$ and $4^{\text {th }}$ from the left and all of the bottom row). Kenmotsu $(1991: 200,204)$ argues that the presence of gunflints made from a black English chert (Brandon flint) is indicative of a post-A.D. 1790 occupation, while French blade gunflints were not widely produced until after A.D. 1740.

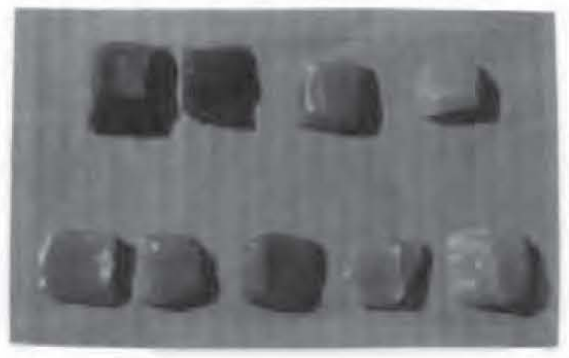

Figure 10. Gunflints.

On this basis, the black flint gunflints from the Indian Springs \#2 site can probably be associated with the early $19^{\text {th }}$ century Anglo-American occupation rather than that of the Kadohadacho, since the Kadohadacho left this part of the Red River valley around 1790 . after which they moved south to near Caddo Lake (Parsons et al. 2002:6). The honeycolored French blade gunflints are probably part of the historic Kadohadacho occupation of the site.

\section{Metal Artifacts}

There are three metal artifacts in the Indian Springs \#2 collection. One is a badly rusted iron case knife (see Harris et al. 1965: Figure 20e-f), that is lacking the handle (Figure 11). The two others are made of cuprous materials (Figure 12a-b). The first of these is a decorated piece that may be part of a side plate to a flintlock musket (Figure 12a), and the other-a rectangular-shaped fragment - may be a piece from a copper kettle bail ear (Brain 1979:166).

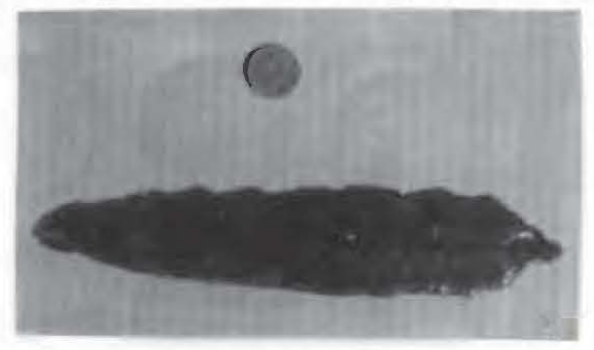

Figure 11. Case knive from the Indian Springs \#2 site.

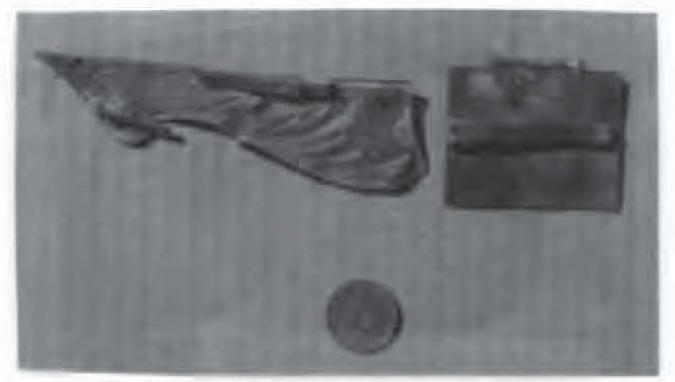

Figure 12. Other metal artifacts: left, possible gun part; right, possible copper kettle piece. 


\section{English ceramic sherds}

Over 100 transfer-printed and shell-edged English ceramics were in the collection from Cranfill's investigation. They are pearlware and whiteware ceramics, and date from ca. $1800-1860$, and are thus unrelated to the historic Kadohadacho settlement at the Indian Springs \#2 site.

There are many sherds from both blue and green shell-edged plates and platters (Figure 13a-b). The green shell-edged sherds are from edge embossed vessels with scalloped rims (see Figure 13b). These particular vessels were probably made and used between ca. 1800-1860, though Hunter and Miller (1994: Plate VII) illustrates vessels like these that were made between ca. 1820-1835. The blue shell-edged plates have even scalloped rims (ca. 1810-1835) and unscalloped rims with impressed lines (ca. 1830-1860); blue scalloped rims are more common in the collection, suggesting most of it was deposited in the early part of the $19^{\text {th }}$ century (see Hunter and Miller 1994).

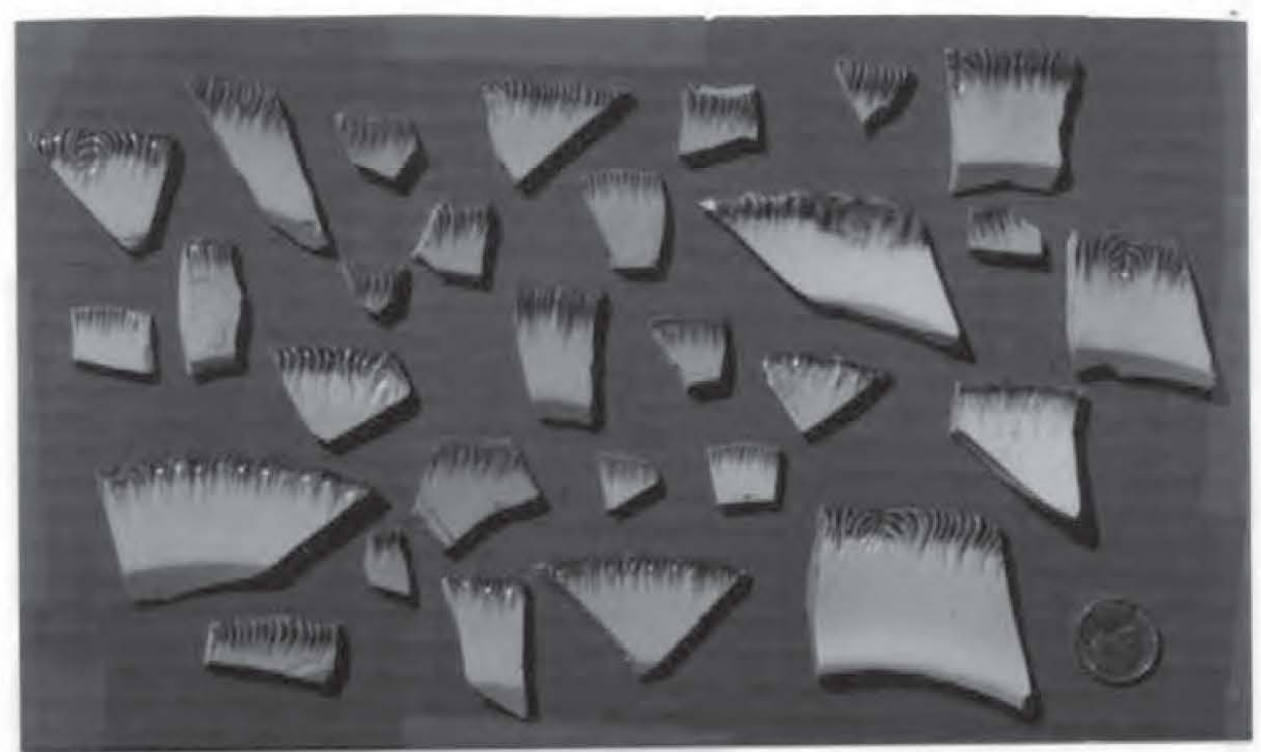

A

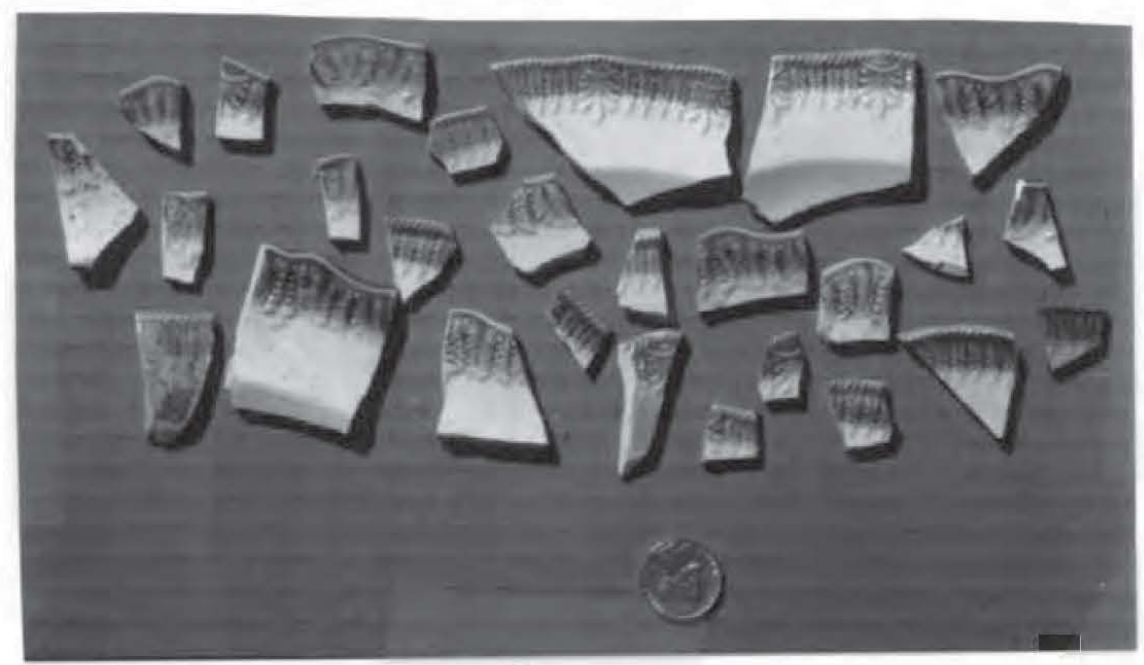

B

Figure 13. Shell-edged sherds: a, blue shell-edged; b, green shell-edged sherds. 
The transfer-printed wares (Figure 14a-b) are medium and dark blue in color, and have printed floral and animal motifs. According to Samford (1997: Table 5), the range of production of these colors for printed wares are 1802-1846 for the dark blue color and 1784-1859 for the medium blue transfer prints. The mean beginning and end production dates are 1817-1835.

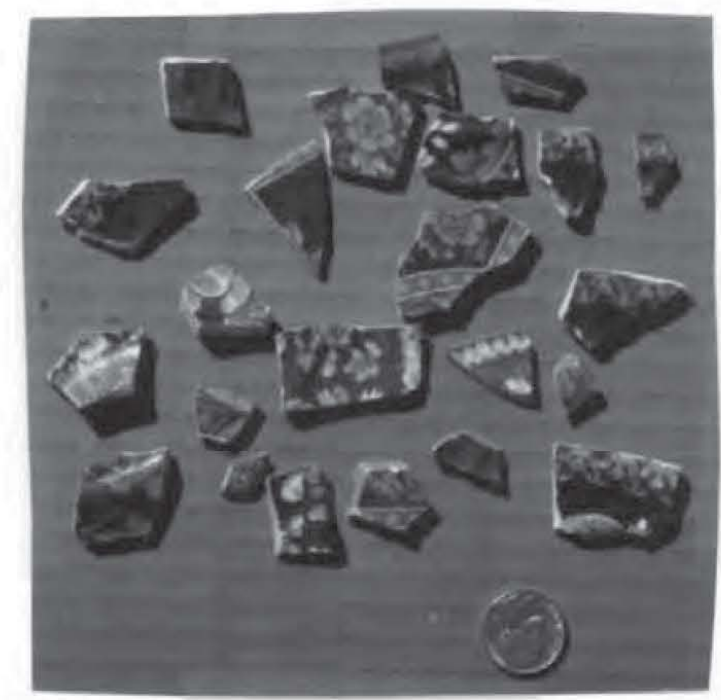

a

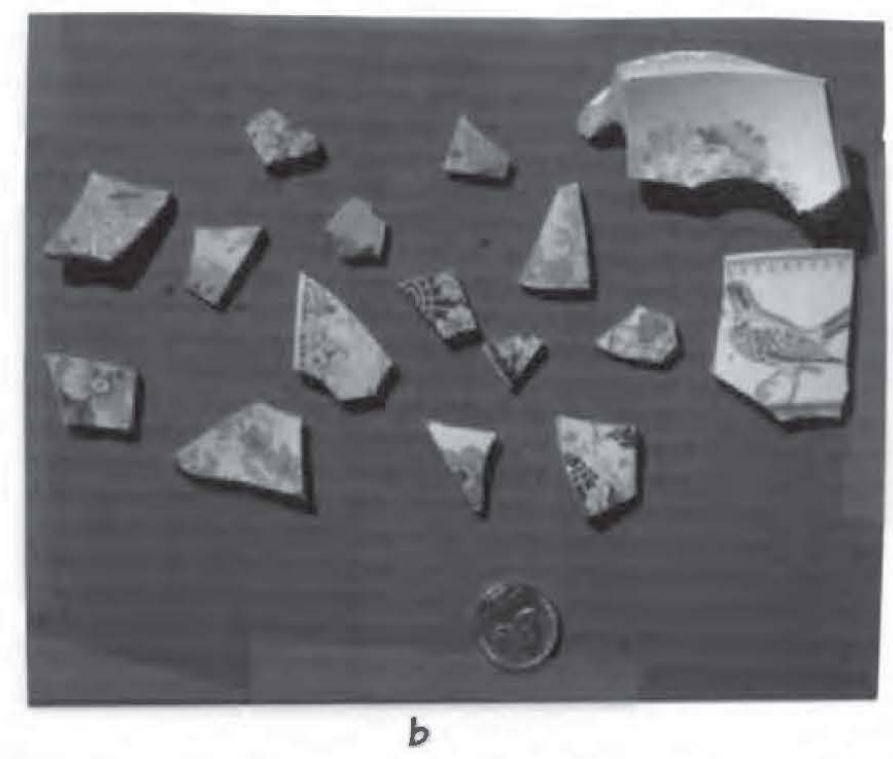

Figure 14. Transfer-printed sherds: a, dark blue printed; $b$, medium blue printed.

\section{Early-1990s Shovel Testing}

With the assistance of Bo Nelson and Mike Turner, in April 1993 we excavated a total of eight shovel tests and one $50 \times 50 \mathrm{~cm}$ unit (ST 7) on the Indian Springs \#2 site (see Figure 1). Most of the shovel tests were on the knoll at the eastern end of the landform; 
other knolls in this general area had been eroded, and the B-horizon clay was exposed at or very near the surface. No artifacts were recovered in ST 3 on the southern knoll, and only two pieces of lithic debris came from ST 5 on the western knoll.

All of the shovel tests and the $50 \times 50 \mathrm{~cm}$ unit on the eastern knoll encountered archaeological deposits and artifacts. The archaeological deposit averaged about $30-40 \mathrm{~cm}$ in thickness, overlying a B-horizon clay. The highest artifact densities were in ST 1 (ca. 168 artifacts per square meter) and ST 8 (ca. 224 artifacts per square meter), and in ST 7 (the 50 $x 50 \mathrm{~cm}$ unit), the artifact density is estimated at 260 per square meter.

Aboriginal artifacts found in the eastern knoll include 55 pieces of lithic debris (primarily from ST 8, $n=22$, and ST 7, $n=10$ ), one pieces of burned clay (ST 7), and two plain ceramic body sherds ( 1 each from ST 2 and ST 4). Most of the artifacts found on this part of the Indian Springs \#2 site are historic in age. However, most of these relate to a late $19^{\text {th }}$-early $20^{\text {th }}$ century occupation, because we recovered wire nails $(n=19)$, lead-glazed stoneware ( $n=1$, popular between ca. 1870-1900), and glass fruit jar sherds $(n=2)$. There were also clear, brown, and aqua-colored bottle glass ( $n=49)$, plain whitewareceramic sherds $(n=4)$, as well as four cut nails from ST 7 and ST 8. Given the proportion of wire to cut nails ( $83 \%$ vs. $17 \%$ ), this historic occupation may have taken place around ca. 1899 1900 (cf. Adams 2002: Figure 1 and Table 3 ). No late $18^{\text {th }}$ or early $19^{\text {th }}$ century artifact were recovered in our limited shovel testing investigations.

\section{Summary and Conclusions}

The Indian Springs \#2 site (41BW512), among other things, is a historic Kadohadacho settlement and cemetery on a bluff overlooking the Red River floodplain. The site was found by the landowner, Mr. Julian Cranfill, in the early 1980s, and during his investigations he recovered a large sample of European glass trade beads, a few other European goods (gunflints and metal objects), along with several whole ceramic vessels and a sample of ceramic sherds. The glass beads and the whole vessels were apparently funerary offerings included in the burial pits of two Caddo Indians.

Mr. Cranfill permitted his important collection to be documented, and made available any notes he had on the work. In 1993, a number of shovel tests were excavated on the knoll where Mr. Crandill had recovered evidence for an historic $18^{\text {th }}$ century Caddo occupation, but none of the archaeological materials found during the shovel testing is apparently associated with this occupation.

In the absence of any radiocarbon dates on the archaeological deposits at the site, I rely on the several thousand glass beads recovered by Mr. Cranfill from the two burial features there to suggest that the Indian Springs \#2 site was occupied by a group of Kadohadacho Caddo between ca. 1760-1790. The specific Kadohadacho group is not known, but the site is not far from the historic placement of the Nanatsoho and upper Natchitoches Caddo groups (Swanton 1942: Map 1). About 30 years or so after the Kadohadacho had left this area because of the effects of European-introduced diseases and attacks from the Osage, it appears that the Indian Springs \#2 site was then occupied by an Anglo-American family.

\section{Acknowledgments}

I very much appreciate the willingness of Julian Cranfill to let us examine his collection from the Indian Springs \#2 site, and for giving us permission to excavate a few 
shovel tests on the site. Bo Nelson and Mike Turner assisted with the excavation of the shovel tests. Nancy Reese is acknowledged for her help in preparing Figures 1-3 in this article.

\section{References Cited}

Adams, W. H.

2002 Machine Cut Nails and Wire Nails: American Production and Use for Dating $19^{\text {th }}$ Century and Early-20 ${ }^{\text {th }}$-Century Sites. Hislorical Archaeology 36(4):66-88.

Brain, J.P.

1979 Tunica Treasure. Volume 71, Papers of the Peabody Museum of Archaeology and Ethnology. Harvard University, Cambridge, Massachusetts.

Gonzalez, B.

2005 Caddo Tribal Religious Burial Ceremonies beyond Archeology. In A Rediscovering of Caddo Herilage: The W.T. Scolt Collection at the American Museum of Natural History and Other Caddo Collections from Arkansas and Louisiana, by B.

Gonzalez, R. Cast, T. K. Perttula, and B. Nelson, pp. 55-59. Historic Preservation Program, Caddo Nation of Oklahoma, Binger, Oklahoma.

Gonzalez, B., R. Cast, T. K. Perttula, and B. Nelson

2005 A Rediscovering of Caddo Herilage: The W.T. Scotl Collection at the American Museum of Natural History and Other Caddo Collections from Arkansas and Louisiana. Historic Preservation Program, Caddo Nation of Oklahoma, Binger, Oklahoma.

Harris, R. K., I. M. Harris, J. C. Blaine, and J. Blaine

1965 A Preliminary Archeological and Documentary Study of the Womack Site, Lamar County, Texas. Bulletin of the Texas Archeological Society 36:287-363.

Hunter, R. R., Jr. and G. L. Miller

1994 English Shell-Edged Earthenware. Antiques 155(3):432-443.

Kenmotsu, N. A.

1991 Gunflints: A Study. In Approaches to Material Culture Research for Historical Archaeologists, compiled by G. L. Miller, O. R. Jones, L. A. Ross, and T. Majewski, pp. 197-221. The Society for Historical Archaeology, California, Pennsylvania.

Parsons, M. L., J. E. Bruseth, J. Bagur, S. E. Goldborer, and C. McCrocklin 2002 Finding Sha'chahdinnih (Timber Hill): The Last Village of the Kadohadacho in the Caddo Homeland. Archeological Report Series No. 3. Texas Historical Commission, Austin.

Perttula, T. K.

2001 Three Mid-1800s Caddo Vessels from the Brazos Reserve. Journal of Northeast Texas Archaeology 14:31-36.

200541 HO64/41 HO65, Late $17^{\text {th }}$ to Early $18^{\text {th }}$ Century Caddo Sites on San Pedro Creek in Houston County, Texas. Bulletin of the Texas Archeological Society 75:85-103. 
Perttula, T. K. and J. C. Blaine

1998 Historic European Trade Goods from the Willis Place \#2 (41BW147) Site in Bowie County, Texas. Journal of Northeast Texas Archaeology 11:91-92.

Samford, P. M.

1997 Response to a Market: Dating English Underglaze Transfer-Printed Wares. Historical Archaeology 31(2):1-30.

Smith, M. T.

2002 Eighteenth-Century Glass Beads in the French Colonial Trade. Historical Archaeology 36(1):55-61.

Story, D. A., B. Barber, E. Barber, E. Cobb, H. Cobb, R. Coleman, K. Gilmore, R. K. Harris, and N. Hoffrichter

1967 Pottery Vessels. In The Gilbert Site: A Norteno Focus Site in Northeastern Texas, edited by E. B. Jelks, pp. 112-187. Bulletin of the Texas Archeological Society 37.

Swanton, J. R.

1942 Source Material on the History and Ethnology of the Caddo Indians. Bulletin No. 132. Bureau of American Ethnology, Smithsonian Institution, Washington, D.C.

Walker, W. M.

1935 A Caddo Burial at Natchitoches, Louisiana. Smithsonian Miscellaneous Collections, Vol. 94, No. 14. Smithsonian Institution, Washington. D.C. 